medRxiv preprint doi: https://doi.org/10.1101/2020.07.01.20143917; this version posted July 3, 2020. The copyright holder for this preprint (which was not certified by peer review) is the author/funder, who has granted medRxiv a license to display the preprint in perpetuity.

\title{
Relative COVID-19 viral persistence and antibody kinetics
}

\section{Authors}

Chung-Guei Huang, Ph.D. $;^{1,2,3, \#}$ Ching-Tai Huang, M.D.,Ph.D. ${ }^{4,5, \#}$ Avijit Dutta, Ph.D.; ${ }^{4}$ PiYueh Chang, Ph.D.; ${ }^{1,2}$ Mei-Jen Hsiao, M.S.; ; ${ }^{1,2}$ Yu-Chia Hsieh, M.D.,Ph.D. ;6,7 Shin-Ru Shih, Ph.D. $;^{1,2,3}$ Kuo-Chien Tsao, B.S.; ${ }^{1,2}$ Cheng-Ta Yang, M.D. ${ }^{8,9, \star}$

\section{Affiliations}

${ }^{1}$ Department of Laboratory Medicine, Chang Gung Memorial Hospital, Taoyuan, Taiwan

${ }^{2}$ Department of Medical Biotechnology and Laboratory Science, College of Medicine, Chang Gung University, Taoyuan, Taiwan

${ }^{3}$ Research Center for Emerging Viral Infections, College of Medicine, Chang Gung University, Taoyuan, Taiwan

${ }^{4}$ Division of infectious diseases, Department of Medicine, Chang Gung Memorial Hospital, Taoyuan, Taiwan

${ }^{5}$ Division of infectious diseases, Department of Medicine, College of Medicine, Chang Gung University, Taoyuan, Taiwan

${ }^{6}$ Division of Infectious Diseases, Department of Pediatrics, Chang Gung Memorial Hospital, Taoyuan, Taiwan.

${ }^{7}$ Division of Infectious Diseases, Department of Pediatrics, College of Medicine, Chang Gung University, Taoyuan, Taiwan

${ }^{8}$ Department of Thoracic Medicine, Chang Gung Memorial Hospital, Taoyuan, Taiwan

${ }^{9}$ Department of Respiratory Therapy, College of Medicine, Chang Gung University,

Taoyuan, Taiwan

\#These authors contributed equally to this work 
medRxiv preprint doi: https://doi.org/10.1101/2020.07.01.20143917; this version posted July 3, 2020. The copyright holder for this preprint (which was not certified by peer review) is the author/funder, who has granted medRxiv a license to display the preprint in perpetuity. It is made available under a CC-BY-ND 4.0 International license.

${ }^{*}$ Correspondence to: Dr. Cheng-Ta Yang, Department of Thoracic Medicine, Chang Gung

Memorial Hospital, Taoyuan, Taiwan. Phone: +886-3-3281200, email:

yang1946@cgmh.org.tw 
medRxiv preprint doi: https://doi.org/10.1101/2020.07.01.20143917; this version posted July 3, 2020. The copyright holder for this preprint (which was not certified by peer review) is the author/funder, who has granted medRxiv a license to display the preprint in perpetuity. It is made available under a CC-BY-ND 4.0 International license.

\section{Key points:}

Question: The key factor for the different "patterns" of COVID-19 antibody response.

Findings: Strong antibody response depends on the relative persistence of the virus, instead of the absolute virus amount. The antibody response is still weak if large amount of virus is cleared quickly. The neutralization efficacy per unit antibody is comparable between high and low antibody patterns. High antibody level contains more inefficient antibodies.

Meaning: Strong response contains inefficient and maybe harmful antibodies. Low antibody response is also equipped with a capable B cell pool of efficient antibodies, which may expand with next virus encounter and confer protection. 
medRxiv preprint doi: https://doi.org/10.1101/2020.07.01.20143917; this version posted July 3, 2020. The copyright holder for this preprint (which was not certified by peer review) is the author/funder, who has granted medRxiv a license to display the preprint in perpetuity.

\section{Abstract}

Importance: The COVID-19 antibody response is a critical indicator for evaluating immunity and also serves as the knowledge base for vaccine development. The picture is still not clear because of many limitations including testing tools, time of sampling, and the unclear impact of varying clinical status. In addition to these problems, antibody levels may not be equivalent to protective capacity.

Objective: To define the key factor for the different patterns of COVID-19 antibody response.

Design: We elucidated the antibody response with time-series throat and serum samples for viral loads and antibody levels, then used a neutralization test to evaluate protectiveness.

Setting: A medical center that typically cares for patients with moderate to severe diseases. Because of the low prevalence of COVID-19 in Taiwan and local government policy, however, we also admit COVID-19 patients with mild disease or even those without symptoms for inpatient care.

Participants: RT-PCR-confirmed COVID-19 patients.

Results: We found that only patients with relative persistence of virus at pharynx displayed strong antibody responses that were proportional to the pharyngeal viral load. They also had proportional neutralization titers per unit of serum. Although antibody levels decreased around 2 weeks after symptom onset, the neutralization efficacy per unit antibody remained steady and even continued to increase over time. The antibody response in patients with rapid virus clearance was weak, but the neutralization efficacy per unit antibody in these patients was comparable to those with persistent presence of virus. The deceased were with higher viral load, higher level of antibody, and higher 
medRxiv preprint doi: https://doi.org/10.1101/2020.07.01.20143917; this version posted July 3, 2020. The copyright holder for this preprint (which was not certified by peer review) is the author/funder, who has granted medRxiv a license to display the preprint in perpetuity. It is made available under a CC-BY-ND 4.0 International license .

neutralization titers in the serum, but the neutralization capacity per unit antibody is relatively low.

Conclusions and Relevance: Strong antibody response depends on the relative persistence of the virus, instead of the absolute virus amount. The antibody response is still weak if large amount of virus is cleared quickly. The neutralization efficacy per unit antibody is comparable between high and low antibody patterns. Strong antibody response contains more inefficient and maybe even harmful antibodies. Low antibody response is also equipped with a capable B cell pool of efficient antibodies, which may expand with next virus encounter and confer protection. 
medRxiv preprint doi: https://doi.org/10.1101/2020.07.01.20143917; this version posted July 3, 2020. The copyright holder for this preprint (which was not certified by peer review) is the author/funder, who has granted medRxiv a license to display the preprint in perpetuity.

\section{Main Text}

In late January 2020, we started to treat RT-PCR (real-time polymerase chain reaction)-confirmed COVID-19 patients. We are a medical center that typically cares for patients with moderate to severe diseases. Because of the low prevalence of COVID-19 in Taiwan and local government policy, however, we also admit COVID-19 patients with mild disease or even those without symptoms for inpatient care. Serial RT-PCR tracking of pharyngeal samples was performed throughout each patient's hospital course. With informed consent from patients or their families, our research was conducted using serum samples remaining after routine medical tests. We used two ELISA-based kits ${ }^{1,2,3}$ to detect anti-spike protein IgG antibodies, and the results of the two were concordant. The tests are semi-quantitative and measure antibody concentrations relative to a cut-off point value in serial dilutions of serum samples. We also cultured virus strains from our patient samples and used one of the strains to quantify the neutralization valence of serum samples in our Biosafety Level-3 laboratory. By mid-March 2020, we had collected serum samples from 15 consecutive patients. As a single center study, we also have complete medical record including detailed travel, occupation, contacts, and cluster history.

Theoretically, the stronger the viral stimulation, the stronger the immune response. We examined the viral load in the first pharyngeal specimens of the 15 patients, represented by E gene RT-PCR Ct value, and checked the association between the viral load and the highest antibody value in their serial serum samples. Seven patients had an absolute concordance. The higher the viral load, the stronger their antibody response, falling on a regression line with a correlation coefficient of 0.95 (Fig. 1). However, eight patients had no such correspondence. There was a clear difference in dynamic changes in the amount of virus at throat between these two groups (Fig. 2A). The virus persisted longer in the 7 patients with direct correlation, compared to the 8 patients with no 
medRxiv preprint doi: https://doi.org/10.1101/2020.07.01.20143917; this version posted July 3, 2020. The copyright holder for this preprint (which was not certified by peer review) is the author/funder, who has granted medRxiv a license to display the preprint in perpetuity.

correlation ( $21.3 \pm 6.5$ versus $12.0 \pm 2.6$ days, $p=.015)$. The mean age of these two groups was also significantly different $(60.1 \pm 10.3$ years, median 65 , versus $38.3 \pm 14.9$ years, median 38, $p=.005)$.

There were many more antibodies in patients with relatively persistent presence of virus than in those with rapid virus clearance (Fig. 2B). The highest antibody levels were $697.9 \pm 384.2$ and $74.8 \pm 88.8$, respectively $(p=.026)$. The neutralization titer in each group was proportional to the amount of antibody (Fig. 2C). The peak neutralization titer was higher in patients with longer persistence of virus $(162.5 \pm 184.6$ versus $29.7 \pm 41.9$, $p=.090)$. High antibody levels were maintained for longer in patients with relative viral persistence. Antibody levels started decreasing $22.7 \pm 8.6$ days after symptom onset in this group, compared to $12.1 \pm 5.6$ days in those with rapid viral clearance $(p=.019)$. The neutralization titers decreased accordingly.

We normalized the neutralization titer by the amount of antibody to determine the neutralization efficacy per unit of antibody. The neutralization efficacy per unit of antibody remained relatively steady or even continued increasing after two weeks (Fig. 3A), although the total antibody quantity and neutralization titer began to decline by that time. Interestingly, the neutralization efficacy per unit antibody was comparable between both groups, irrespective of viral persistence and antibody levels $(41.3 \pm 30.8$ versus $35.7 \pm$ 24.8, $p=.704)$.

Two out of our fifteen patients died. One young man was suspected to have suffered a thrombosis-related acute cardiac event. The other patient was older and had severe heart failure before contracting COVID-19. Although death is not necessarily a result of an inadequate immune response, the patients who died had a high amount of virus in the throat and higher level of antibodies in serum compared to those who survived, but the neutralization efficacy per unit antibody was relatively poor (Fig. 3B). 
medRxiv preprint doi: https://doi.org/10.1101/2020.07.01.20143917; this version posted July 3, 2020. The copyright holder for this preprint (which was not certified by peer review) is the author/funder, who has granted medRxiv a license to display the preprint in perpetuity.

\section{Discussions}

Many factors may contribute to viral persistence in the pharynx, including the size of virus inoculum and the immunity of the host. Slower clearance with relatively persistent presence of the virus induces strong antibody responses. Overall neutralization titers are associated with the amount of antibody per unit of serum. However, even though antibody levels begin to decline two week after symptom onset, the neutralization efficacy per unit of antibody remains the same or continues to increase. This indicates that the proportion of antibodies with lower neutralization efficacy gradually decreases, while the proportion of higher efficacy gradually increases. The phenomenon of neutralization efficacy increasing over time is in line with the known maturation process of the antibody response. Created through random VDJ recombination, the $B$ cell receptor (BCR) repertoire is highly heterogeneous. Clonal selection is achieved through stimulation and response where B cells with BCR and antibodies with effective neutralization ability gradually expand and become the majority of the $\mathrm{B}$ cell pool responding to the virus. This is an evolutionary process that takes time. Neutralization capacity represents the antibody's ability to protect against specific pathogens. It deserves special attention because there is a population of antibodies with poor neutralization capacity in the early stages of the antibody reaction. One of the most concerning risks of convalescent plasma therapy for COVID-19 is that some plasma antibodies may in fact not be protective and could even be harmful due to mechanisms such as Antibody-Dependent Enhancement (ADE). ${ }^{4}$ Therefore we must be cautious about the timing of plasma procurement from the patients who have recovered from the illness.

People tend to try to link the association between the amount of virus in respiratory samples to the severity of illness. However, persistent presence of virus rather than the absolute amount of virus at the throat was responsible for a strong and early antibody 
medRxiv preprint doi: https://doi.org/10.1101/2020.07.01.20143917; this version posted July 3, 2020. The copyright holder for this preprint (which was not certified by peer review) is the author/funder, who has granted medRxiv a license to display the preprint in perpetuity. It is made available under a CC-BY-ND 4.0 International license .

response. A strong and early antibody response is likely predominantly comprised of less protective and potentially even harmful antibodies. In patients with SARS, it has been reported that poor clinical outcomes was associated with early appearance of antibody ${ }^{5}$ Patients with difficulty eradicating the virus suffer from the damage caused by both the virus and the ineffective potentially harmful antibodies. In our study, patients with viral persistence and an earlier and stronger antibody response tend to be older. This may explain the vulnerability to COVID-19 in the elderly.

In our observations, low or even no detectable antibodies did not necessarily represent absence of immunity. Although the absolute antibody quantity in these patients is low, the neutralization efficacy per unit of antibody is equivalent to that of the group with higher antibody levels, indicating that patients with low antibody quantities also have a considerable number of mature B cells secreting effective antibodies. Upon subsequent encounters of the virus, these B cells will likely expand with a memory response and may produce effective antibodies in quantities sufficient to protect the host.

Among our patients, viral load at the throat did not persist for long in most healthcare workers $(\mathrm{HCW})$. Their antibody response was also low. There are many possible reasons for this. These HCW are young. Personal protective equipment (PPE) may have reduced the amount of viral exposure. However, there is still significant morbidity and mortality from COVID-19 among HCW around the world. This may be due to insufficient personal protection or extremely high viral loads in their environment that overcome the protection afforded by PPE. 
medRxiv preprint doi: https://doi.org/10.1101/2020.07.01.20143917; this version posted July 3, 2020. The copyright holder for this preprint (which was not certified by peer review) is the author/funder, who has granted medRxiv a license to display the preprint in perpetuity.

\section{References}

1. Guo L, Ren L, Yang S, et al. Profiling Early Humoral Response to Diagnose Novel Coronavirus Disease (COVID-19). Clin. Infect. Dis. 2020; ciaa310. https://doi.org/10.1093/cid/ciaa310

2. Ong DSY, de Man SJ, Lindeboom FA, Koeleman JGM. Comparison of diagnostic accuracies of rapid serological tests and ELISA to molecular diagnostics in patients with suspected coronavirus disease 2019 presenting to the hospital. Clin. Microbiol. Infect. 2020; S1198-743X(20)30305-0. doi: 10.1016/j.cmi.2020.05.028.

3. Beavis KG, Matushek SM, Abeleda APF, et al. Evaluation of the EUROIMMUN AntiSARS-CoV-2 ELISA Assay for detection of IgA and IgG antibodies. J. Clin. Virol. 2020; 129:104468. doi: 10.1016/j.jcv.2020.104468.

4. Wang SF, Tseng SP, Yen $\mathrm{CH}$, et al. Antibody-dependent SARS coronavirus infection is mediated by antibodies against spike proteins. Biochem. Biophys. Res. Commun. 2014; 451:208-214. doi: 10.1016/j.bbrc.2014.07.090.

5. Ho MS, Chen WJ, Chen WJ, et al. Neutralizing antibody response and SARS severity. Emerg. Infect. Dis. 2005; 11:1730-1737. doi: 10.3201/eid1111.040659. 
medRxiv preprint doi: https://doi.org/10.1101/2020.07.01.20143917; this version posted July 3, 2020. The copyright holder for this preprint (which was not certified by peer review) is the author/funder, who has granted medRxiv a license to display the preprint in perpetuity.

\section{Figures}

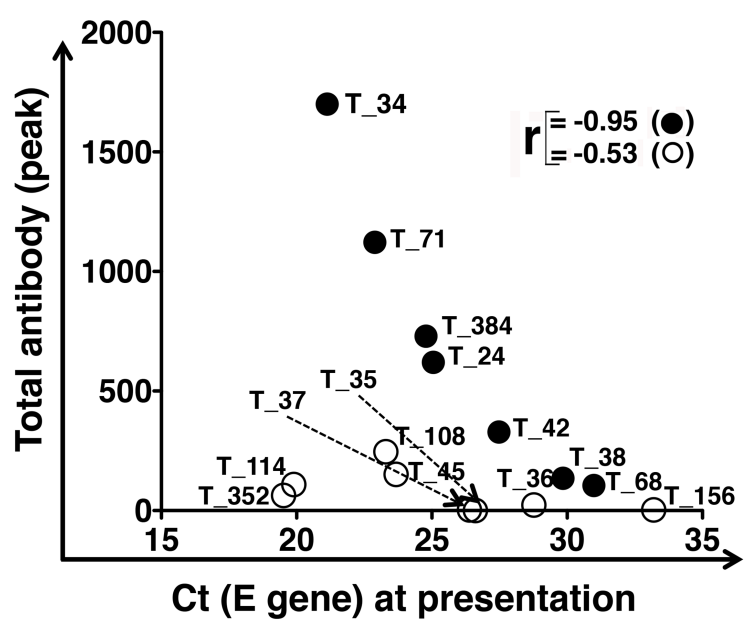

Figure 1. Maximal antibody response and pharyngeal virus load on disease presentation. The highest antibody levels were plotted in the Y-axis against the pharyngeal virus loads on disease presentation, as represented by the Ct values of viral $\mathrm{E}$ gene, in the X-axis. Seven patients in closed circles falls on a regression line of correlation coefficient 0.95 . There is no correlation between the maximal antibody response and pharyngeal virus loads on disease presentation for the other 8 patients in open circles. The patients are tagged by our national serial number of COVID-19 cases. 
A

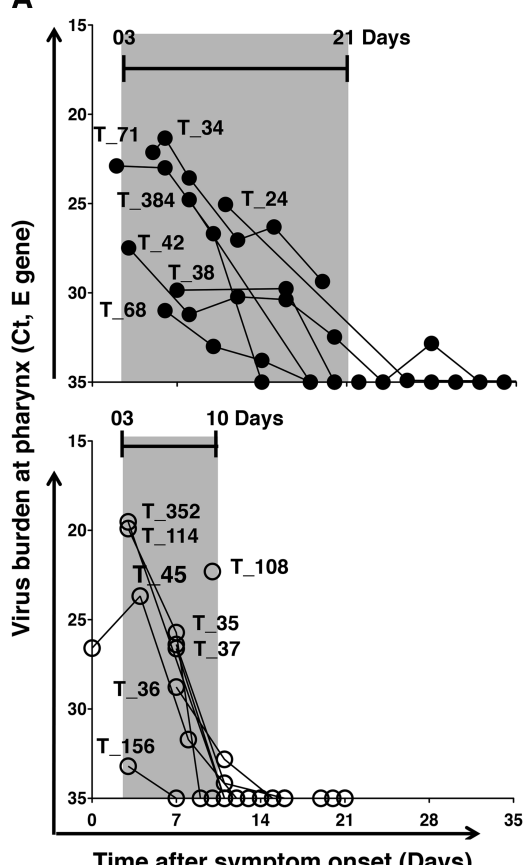

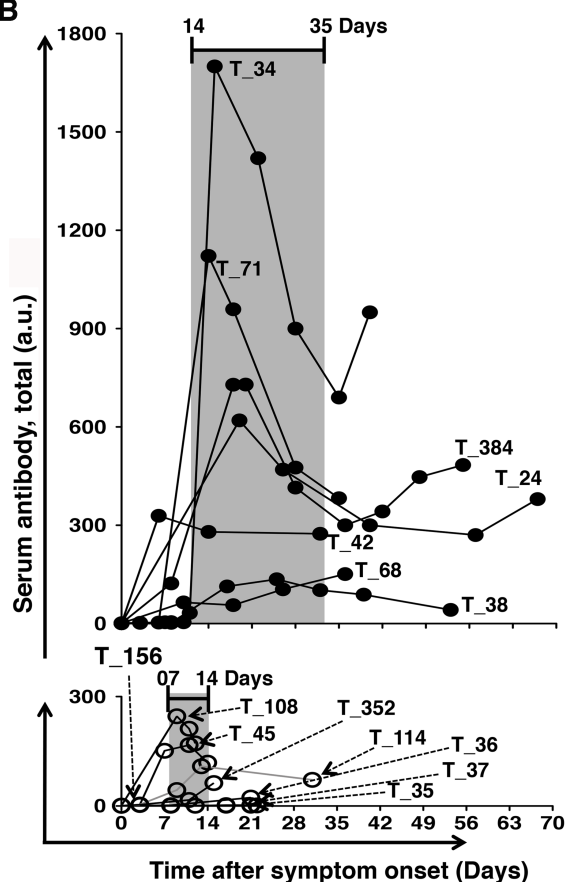

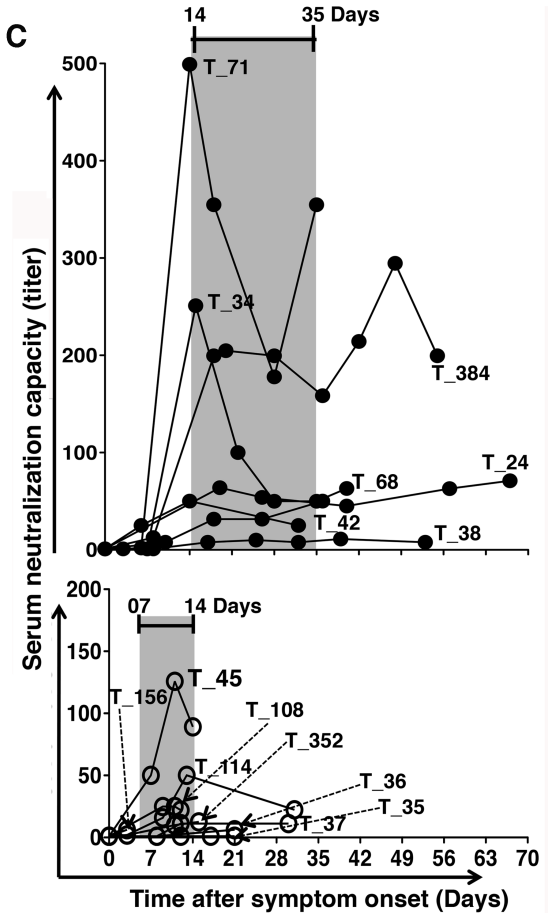

Figure 2. Dynamic changes in pharyngeal virus load, serum antibody and ne utralization titer. (A) Seven patients with maximal antibody levels corresponding to virus loads on presentation (closed circles) revealed delayed clearance of virus from the throat. On the contrary, the other 8 cases with no correlation (open circles) eradicated the virus from the throat quickly. (B) The antibody response was significantly stronger in patients with delayed clearance compared to patients with rapid eradication. (C) The neutralization capacity was proportional to the amount of antibody in unit of serum. The neutralization valence was significantly higher in patients with persistent presence of the virus than patients with shorter presence of the virus. The patients are tagged by our national serial number of COVID-19 cases. 
A
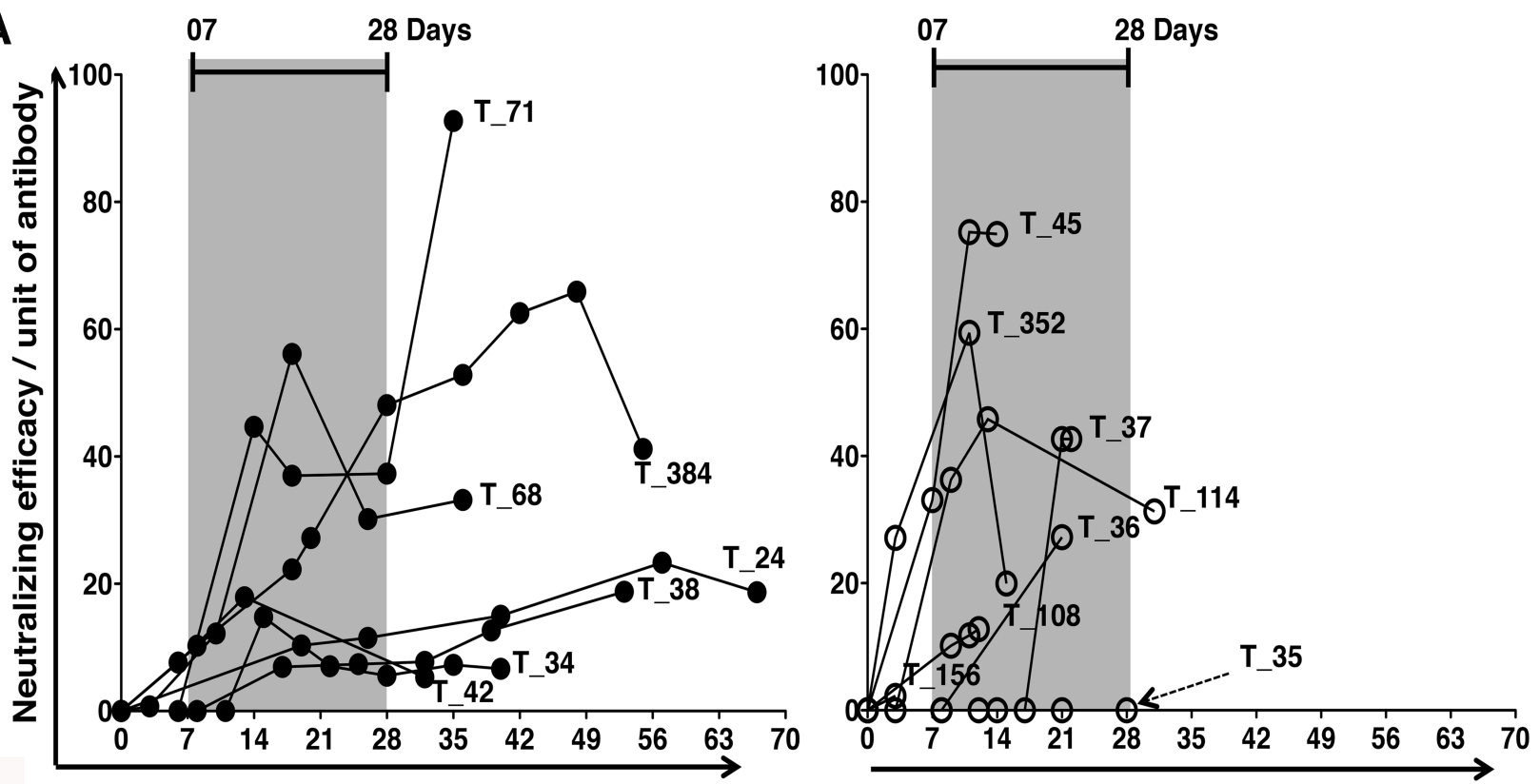

Time after symptom onset (Days)

B

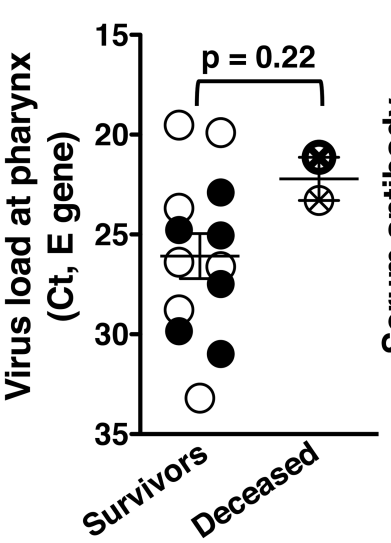

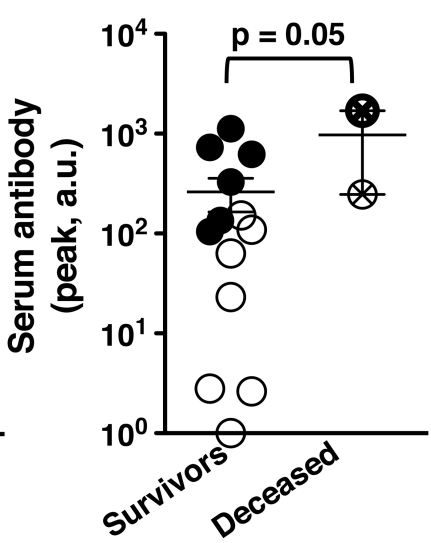
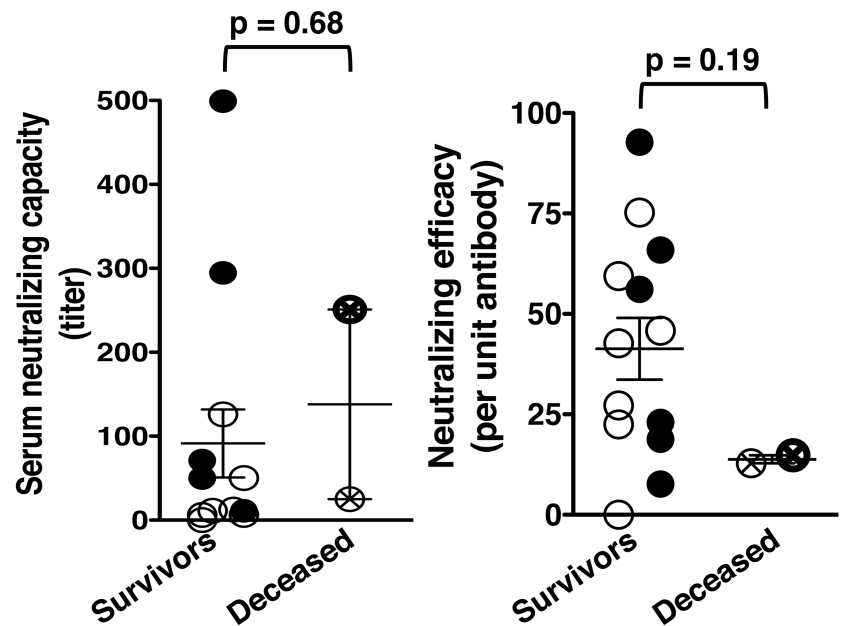

Figure 3. Neutralization efficacy per unit of antibody. (A) Even though the total antibody and neutralization capacity per unit of serum are significantly higher in patients with viral persistence, the neutralization efficacy per unit of antibody are comparable between patients with viral persistence (Left panel, closed circles) and patients with rapid eradication (Right panel, open circles). (B) The deceased (the two circles with a cross) were with high viral loads on presentation, higher amount and higher neutralization valence in unit of serum, but they had lower neutralization efficacy per unit of antibody compared to the survived (non-crossed circles, either closed or open). 
medRxiv preprint doi: https://doi.org/10.1101/2020.07.01.20143917; this version posted July 3, 2020. The copyright holder for this preprint (which was not certified by peer review) is the author/funder, who has granted medRxiv a license to display the preprint in perpetuity.

\section{Methods}

\section{CoVID-19 Nucleic acid detection}

Nasopharyngeal or oropharyngeal throat swab specimens were collected from patients. Test for COVID-19 nucleic acid followed standard protocols. RNA was extracted from clinical samples with the LabTurbo system (Taigen, Taiwan). A $25 \mu \mathrm{L}$ reaction contained $5 \mu \mathrm{L}$ of RNA, $12.5 \mu \mathrm{L}$ of $2 \times$ reaction buffer provided with the Superscript III one step RTPCR system with Platinum Taq Polymerase (AgPath-ID One-step RT-PCR Kit), $1 \mu \mathrm{L}$ of reverse transcriptase/Taq mixture from the kit, $0.4 \mu \mathrm{L}$ of a $50 \mathrm{mM}$ magnesium sulphate solution (Invitrogen), and $1 \mu \mathrm{g}$ of nonacetylated bovine serum albumin (Roche). All oligonucleotides were synthesized and provided by Tib-Molbiol (Berlin, Germany). Thermal cycling was performed at $48^{\circ} \mathrm{C}$ for 30 min for reverse transcription, followed by $95^{\circ} \mathrm{C}$ for 10 min and then 45 cycles of $95^{\circ} \mathrm{C}$ for $10 \mathrm{~s}, 65^{\circ} \mathrm{C}$ for $30 \mathrm{~s}$.

Reference: Corman VM, Landt O, Kaiser M, et al. Detection of 2019 novel coronavirus (2019-nCoV) by real-time RT-PCR. Euro Surveill. 2020; 25:2000045.

\section{COVID-19 Serum antibody detection}

To evaluate the antibody response, the levels of total IgG in patients' sera were semiquantified by ELISA (cat No. WS-1096, WANTAI SARS-CoV-2 Ab ELISA, China). WANTAI SARS-CoV-2 Ab ELISA is a two step incubation antigen "sandwich" enzyme immunoassay kit, which uses polystyrene microwell strips pre-coated with recombinant SARS-CoV-2 antigen. Patient's serum or plasma specimen is added, and during the first incubation, the specific SARS-CoV-2 antibodies will be captured inside the wells, if present. The microwells are then washed to remove unbound serum proteins. Second recombinant SARS-CoV-2 antigen conjugated to the enzyme Horseradish Peroxidase (HRP-Conjugate) is added, and during the second incubation, the conjugated antigen will bind to the 
medRxiv preprint doi: https://doi.org/10.1101/2020.07.01.20143917; this version posted July 3, 2020. The copyright holder for this preprint (which was not certified by peer review) is the author/funder, who has granted medRxiv a license to display the preprint in perpetuity. It is made available under a CC-BY-ND 4.0 International license .

captured antibody inside the wells. The microwells are then washed to remove unbound conjugate, and Chromogen solutions are added into the wells. In wells containing the antigen-antibody-antigen(HRP) "sandwich" immunocomplex, the colorless Chromogens are hydrolyzed by the bound HRP conjugate to a blue colored product. The blue color turns yellow after the reaction is stopped with sulfuric acid. The amount of color intensity can be measured and it is proportional to the amount of antibody captured inside the wells, and to the specimen respectively. Wells containing specimens negative for SARS-CoV-2 antibodies remain colorless. The results had been verified with another ELISA kit (AntiSARS-CoV-2 ELISA IgG, Euroimmun, Germany), the ELISA results got good agreement in both kits.

\section{Neutralization Antibody Test (NAT)}

The neutralizing antibody test of COVID-19 followed the standard protocol of a plaque reduction neutralization test. Vero cells were regularly maintained in minimal essential medium (MEM) supplemented with 10\% (v/v) fetal bovine serum (FBS). COVID-19 virus was propagated in Vero cells in maintenance medium consisting of MEM supplemented with $0 \%$ FBS. Serum samples were inactivated at $56^{\circ} \mathrm{C}$ for 30 min prior to use. Serial twofold dilutions of sera were mixed with an equal volume of COVID-19 virus suspension containing $100 \times$ the median tissue culture infectious dose $\left(T_{C I D}\right)$. The mixture was incubated for $2 \mathrm{hr}$ at $37^{\circ} \mathrm{C}$ and then an equal volume of suspended VeroE6 cells (approximately 30,000 cells/well) were added to each well. Following incubation for 1 week at $37^{\circ} \mathrm{C}$, cells were fixed with $5 \%$ glutaraldehyde and stained with $0.1 \%$ crystal violet. Serum neutralization titers were calculated and expressed as the reciprocals of the highest serum dilution that inhibits cytopathic effects. 
medRxiv preprint doi: https://doi.org/10.1101/2020.07.01.20143917; this version posted July 3, 2020. The copyright holder for this preprint (which was not certified by peer review) is the author/funder, who has granted medRxiv a license to display the preprint in perpetuity. It is made available under a CC-BY-ND 4.0 International license.

\section{Statistical analysis}

We used Graph Pad Prism version 5 for statistical analyses. Data represented as mean \pm

SD and $p$ values for two-tailed unpaired Student's t-test in the text. 